This is an electronic reprint of the original article. This reprint may differ from the original in pagination and typographic detail.

Author(s): Haapalehto, Tuomas; Kotiaho, Janne Sakari; Matilainen, Rose; Tahvanainen, Teemu

Title: $\quad$ The effects of long-term drainage and subsequent restoration on water table level and pore water chemistry in boreal peatlands

Year: $\quad 2014$

Version:

Please cite the original version:

Haapalehto, T., Kotiaho, J. S., Matilainen, R., \& Tahvanainen, T. (2014). The effects of long-term drainage and subsequent restoration on water table level and pore water chemistry in boreal peatlands. Journal of Hydrology, 519(Part B), 1493-1505. https://doi.org/10.1016/j.jhydrol.2014.09.013

All material supplied via JYX is protected by copyright and other intellectual property rights, and duplication or sale of all or part of any of the repository collections is not permitted, except that material may be duplicated by you for your research use or educational purposes in electronic or print form. You must obtain permission for any other use. Electronic or print copies may not be offered, whether for sale or otherwise to anyone who is not an authorised user. 


\title{
THE EFFECTS OF LONG-TERM DRAINAGE AND SUBSEQUENT RESTORATION ON WATER TABLE LEVEL AND PORE WATER CHEMISTRY IN BOREAL PEATLANDS
}

\author{
Haapalehto, T. ${ }^{12^{*}}$, Kotiaho, J.S. ${ }^{1}$, Matilainen, R. ${ }^{3}$, \& Tahvanainen, T. ${ }^{4}$
}

${ }^{1}$ Department of Biological and Environmental Science, P.O. Box 35, 40014 University of Jyväskylä, Finland.

${ }^{2}$ Metsähallitus, Natural Heritage Services, P.O. Box 36, 40101 Jyväskylä, Finland.

${ }^{3}$ Department of Chemistry, P.O. Box 35, 40014 University of Jyväskylä, Finland.

${ }^{4}$ Department of Biology, University of Eastern Finland, P.O.Box 111, 80101 Joensuu,

Finland

*Corresponding author; E-mail: tuomas.o.haapalehto@student.jyu.fi, tuomas.haapalehto@metsa.fi, mobile: +358 403532480

Abbreviated title: Degradation and restoration of peatland hydrology

Keywords: anthropogenic disturbance, ecosystem function, ecosystem services, spatial variation, hydrology, wetland 


\begin{abstract}
Degradation by drainage threatens biodiversity and globally important peatland ecosystem functions such as long-term carbon sequestration in peat. Restoration aims at safeguarding peatland values by recovering natural hydrology. Long-term effects of drainage and subsequent restoration, especially related to within-site variation of water table level and pore water chemistry, are poorly known. We studied hydrological variation at 38 boreal Sphagnum peatland sites (pristine, drained and restored) in Finland. Drainage decreased the average water table level especially near the ditches for decades and induced water chemical changes such as increased DOC concentration in peat pore water. There were also large differences in water chemistry between the samples collected from ditches and from the peat strips between the ditches. For example, the ditch water had apparently higher minerogenic influence, while DOC concentrations were highest in peat strips. Restoration was effective in regaining the natural water table level and induced a recovery of pore water chemistry towards the targeted pristine conditions. Restoration also resulted in lessened water chemical differences between ditches and peat strips indicating successful decrease of drainage-induced artificial within-site variation in water chemistry. The water table level in filled ditches was on average slightly lowered compared to surrounding areas 10 years after restoration. While such a difference may be an early warning sign for incomplete recovery of hydrology in long-term, we found no chemical evidence supporting this assumption yet. Our study suggests that restoration can result in significant recovery of peatland hydrology within 10 years, while some deviation from pristine peatlands is still typical. Restoration has a potential to reduce leaching of nutrients and DOC to downstream waters in the long term, but practitioners should be prepared for temporary increase of leaching of $\mathrm{N}$ and $\mathrm{P}$ for at least five years after restoration of boreal Sphagnum peatlands.
\end{abstract}

\title{
1. Introduction
}

Hydrological factors regulate central ecosystem functions like the flow of nutrients and development of soils. These functions enable the provision of globally important ecosystem services such as food crops, timber and many other biological products (Millennium Ecosystem Assessment 2005). By influence on the carrying capacity and niche formation in ecosystems, hydrology is an important driver of biodiversity thus forming the basis for ecosystem services (Millennium Ecosystem Assessment 2005; Konar et al. 2013). The significance of hydrology on ecosystem functions and services is emphasized in northern boreal and subarctic peatlands that cover only $3 \%$ of Earth's land surface but constitute one third of the global terrestrial carbon pool (Yu 2011). Water level fluctuations and water chemistry largely control the accumulation and decomposition of peat and consequent fluxes of carbon as $\mathrm{CO}_{2}, \mathrm{CH}_{4}$ and as dissolved organic carbon (DOC) in peatlands (Moore and Knowles 1989; Tranvik and Jansson 2002; Belyea and Malmer 2004; Holden 2005; Jungkunst and Fiedler 2007).

Like many other ecosystems (Foley et al. 2005), peatlands have been severely degraded. Approximately 50 million hectares $(13 \%)$ of peatlands have been directly altered by human land-use (Lappalainen 1996; Strack 2008; Tanneberger and Wichtmann 2011). One 
major cause of degradation of peatlands is drainage for timber production, affecting approximately 15 million hectares in the northern boreal and subarctic regions (Strack 2008). Drainage of certain peatland areas may also induce significant changes beyond considerable distances within the same catchments to hydrology of undrained peatland areas due to catchment-scale disruption of hydrological connections (Tahvanainen 2011). The total peatland area impacted negatively by drainage and other land-use may, therefore, be much larger than often reported based on the actual drained areas. Drainage lowers the water table level generally by $20-60 \mathrm{~cm}$ with typical spatial pattern related to the distance from the ditch (Laine and Vanha-Majamaa 1992; Prévost et al. 1999; Price et al. 2003). Ditches act as main water flow channels through drained peatlands, and prevent the spread of minerogenic water from the catchment over the peatland surface. Because of the lowered water table level, drainage increases aeration and promotes decomposition and nutrient mineralization in the peat matrix (Niedermeier and Robinson 2007). Subsequently, $\mathrm{pH}$ and concentrations of several chemical elements increase in the pore and outflow water shortly after drainage (Prévost et al. 1999; Åström et al. 2001; Holden et al. 2004; Moore et al. 2013). In contrast, long-term changes of pore water chemistry after drainage are not well understood (Holden et al. 2004). Indeed, understanding the changes in pore water, which is in direct contact to the peat, might help e.g. to explain the apparently contradictory results from studies exploring the effects of drainage and landuse on increased riverine DOC around northern hemisphere (Freeman et al. 2004; Sarkkola et al. 2009; Räike et al. 2012; Huotari et al. 2013).

There is an increasing pressure toward ecological restoration in response to anthropogenic degradation of ecosystems. In general, restoration aims at reversing the degradation by partial rehabilitation or complete restoration of original structure (community composition) and function (e.g. cycling and fluxes of nutrients) of ecosystems (Dobson et al. 1997; Society for Ecological Restoration International 2004; Suding 2011). Precise aims of peatland restoration may differ due to different causes and varying extent of degradation. Most importantly, however, peatland restoration aims at recovering the original hydrological patterns (water table level, water chemistry, water flow paths), which would allow re-establishment of viable populations of characteristic peatland species (Vasander et al. 2003; Aapala et al. 2009). The societal expectations for restoration in securing biodiversity and provision of ecosystem services are monumental; a global target to restore $15 \%$ of degraded ecosystems by 2020 was set recently (Convention on Biological Diversity 2010; European Commission 2011). However, recent meta-analyses question the projected positive impacts of restoration in general (Benayas et al. 2009), and specifically in the case of peatlands (Moreno-Mateos et al. 2012). Possible failures in reaching restoration targets call for better mechanistic understanding of the underlying key-factors for successful restoration, such as hydrological variation in the case of peatlands.

Early results on the hydrological recovery of peatlands are now starting to accumulate, but they seem to be controversial to some extent. For example, both successes and failures of regaining original water table level (Worrall et al. 2007; Klimkowska et al. 2010; Haapalehto et al. 2011; Laine et al. 2011; Hedberg et al. 2012; Schimelpfenig et al. 2013) as well as both intended and unintended effects on water chemistry (Höll et al. 2009; Koskinen et al. 2011; Wilson et al. 2011a, b) have been reported. While bringing urgently needed data on the 
poorly understood hydrological effects of peatland restoration, most studies have covered only a few sites and only the time period of first few years after restoration. Indeed, properly replicated studies on the hydrological recovery of peatlands are called for (Holden et al. 2011; Wilson et al. 2011a) to judge the generality and overall impact of restoration in the longer-term. One important but poorly understood hydrological aspect is the recovery of within-site variation in hydrology. Even relatively moderate patterns of peatland surface topography, such as hummocks and hollows, affect water flow paths and the development of plant communities (Bragazza and Gerdol 1999). Subsidence of peat after drainage is typically uneven and depends on the distance from the ditches (van der Schaaf 2012). This leads to a considerable increase of topographic variation in drained peatlands and provides a challenge for restoration practitioners. Insufficient blocking of ditches can, for example, redirect water flow along the artificial flow paths formed by the lines of blocked ditches. This may, in turn, act to sustain hydrological differences (related to water table level and water chemistry) between the blocked ditches and the intervening peat strips. Such uneven hydrological recovery is, indeed, suggested to hamper the recovery of communities (Hedberg et al. 2012). Therefore, it is vital for our overarching goal of restoration, to better understand the effects of restoration on the hydrological variation within restored sites.

Here we explore the long-term effects of drainage and subsequent ecological restoration on the hydrology of peatlands with special attention paid to within-site hydrological variation. We use a replicated comparative experimental design in which the 38 study sites on boreal Sphagnum peatlands in southern Finland were divided into four categories according to their management status (pristine, forestry drained, restored five years ago and restored 10 years ago). We asked:

1. What is the long-term effect of drainage on water table level and pore water chemistry?

2. To what extent is ecological restoration effective in reversing the effects of drainage on water table level and pore water chemistry?

We measured water table level five times during one growing season and collected water samples for chemistry analyses once at each site. The effects of drainage and restoration on water table level were determined by comparing average seasonal water table levels and differences in within-site water table level variation between pristine, drained and restored sites. Effects of drainage and restoration on pore water chemistry were studied by analyzing the effects of drainage and restoration as well as sampling location (ditch or adjacent peat strip) on the values derived from principal component analysis and measurements of single chemical variables.

\section{Methods}

\subsection{Study sites}

The study area is located in Southern Finland between $61^{\circ} 53^{\prime}$ and $62^{\circ} 51^{\prime} \mathrm{N}$ and $22^{\circ} 53^{\prime}$ and $25^{\circ} 26^{\prime} \mathrm{E}$ in the south-boreal climatic-phytogeographical zone, where raised bogs are the main type of greater peatland formations. The mean annual temperature is ca. $+4^{\circ} \mathrm{C}$ and precipitation ca. $650 \mathrm{~mm}$. The elevation above sea level is around 150 meters. The area 
belongs to the Early Proterozoic bedrock area, characterized by silicaceous granite and granodiorite minerals.

We selected 38 study sites within a $75 \mathrm{~km}$ radius (distances between the sites ranged from $200 \mathrm{~m}-150 \mathrm{~km}$ ) and divided them into four categories according to their management status: i) pristine $(n=10)$, ii) drained $(n=9)$, iii) previously drained and restored 3-7 years before the study (restored 5 years ago, $\mathrm{n}=9$ ), iv) previously drained and restored 9-12 years before the study (restored 10 years ago, $\mathrm{n}=10$ ). For simplification, the categories are referred to Pristine, Drained, Res 5 and Res 10 further on. Selection of the sites was based on close examination of old and new aerial photographs accompanied with field observations, such that the vegetation type (weakly minerotrophic pine fen) and tree stands of the drained and restored sites were originally similar to those of the pristine sites. Study sites were located within larger Sphagnum dominated peatlands consisting of a mosaic of ombro-mesotrophic peatland vegetation types. The sites were considered independent from each other in their surface water flow based on topographic data and field observations. Average peat depth at the sites ranged from $95 \mathrm{~cm}$ to more than $200 \mathrm{~cm}$. The peat was mainly underlain by till i.e. the typical soil type in the region. However, characteristics of the surrounding mineral soils suggest that the underlying soil might be sand at a few sites. The set up may be considered a chronosequence. Such space-for-time substitutions are sometimes problematic in inferring vegetation succession e.g. if the sites differ originally in their properties (Johnson and Miyanishi 2008). We have, however, responded to this challenge by having a number of replicates for each management status. Additionally, special attention is paid to the selection of sites as described above. Significant changes take place in peatland ecosystems after drainage and restoration. Hence, the possibility for slightly larger variation in the original vegetation types of drained and restored sites, when compared to pristine sites, cannot be ruled out. However, we are confident that such marginal differences would not be likely to provide grounds for false interpretation of the results and misleading conclusions.

All of the drained and restored sites were drained for forestry by the state during 1960s and 1970s with ditch interval of 30-50 meters. Fertilization to increase tree growth was a standard procedure at those times, and although no records of the fertilization have been kept, all of the sites were likely fertilized soon after drainage with PK fertilizer. At some of the drained sites ditches had been cleared again in 1990s. Growth of Scotch pine (Pinus sylvestris) and downy birch (Betula pubescens) at originally sparsely pine covered sites had variably increased after the drainage. In 1980s some of the sites were designated to conservation with a subsequent decision to restore them. The restoration measures included filling in the ditches with peat excavated near the ditches, construction of dams and removal of the tree stands in cases where drainage had significantly increased tree growth. The amount of trees removed was adjusted so that all the sites had more or less the same tree cover in the end, mimicking the pre-disturbance tree cover determined from aerial photographs. Restoration was conducted by Natural Heritage Services of Metsähallitus (governmental institution responsible for management of conservation areas). Due to the compression and decomposition the peat near to the ditches has often been observed to be subsided more than the peat elsewhere in the drainage area. Therefore, the filling was supplemented by peat dams elevating $c a .50 \mathrm{~cm}$ over the peat 
surface and extending perpendicularly a few meters at both sides of the ditch to avoid water flow along the subsided areas. For simplification, both the currently active ditches of the drained sites and the in-filled ditches at the restored sites are referred to as 'ditches' further on.

At the Pristine sites, vegetation was characterized by common peatland plants typical to oligotrophic lawn-level peatland vegetation, such as Eriophorum vaginatum, tall-sedges (e.g. Carex rostrata) and Sphagnum mosses (Sphagnum angustifolium, Sphagnum fallax and Sphagnum fuscum). In the Drained sites, common forest plants, such as the dwarf shrubs Vaccinium myrtillus, Vaccinium uliginosum, Vaccinium vitis-idaea, Rhododendron tomentosum and Betula nana dominated the field layer, Pleurozium schreberi along with Sphagnum mosses (Sphagnum angustifolium, Sphagnum magellanicum and Sphagnum russowii) being the most common species in the ground layer. The vegetation changed towards that of Pristine after restoration, with increased abundance of Sphagnum and sedges and decreased abundance of forest shrubs (Kareksela et al. 2014).

\subsection{Measurements of water table level}

Altogether 40 permanent $20-\mathrm{mm}$ polypropylene pipe wells were systematically laid at each study site (Fig. 1). At the drained and restored sites, the wells were placed in five transects running perpendicular to the ditch with each transect having a pair of wells (a sampling unit) at four distances from the ditch $(0,5,10$ and $15 \mathrm{~m})$. As the distance between transects was four meters, the wells formed a rectangular grid with an area of $15 \times 20 \mathrm{~m}$. A similar grid of wells was laid on Pristine sites. At all sites, the location of the first transect (laid in the ditch at drained and restored sites) was randomized. The depth of the water table (the distance of water to peat surface) in each well was measured five times (May, June, July, August, and September) in 2008. Each time, the measurements were taken during a two day period with stable climatic conditions.

The peat surface at the location of each well and the lowest peat surface within each sampling unit were leveled in September 2007. Additionally, we leveled the lowest peat surface at three locations along each transect $(5,10$ and $15 \mathrm{~m}$ from the ditch) at the opposite side of the ditch. Thus, we had altogether 35 leveling values for the lowest peat surface ( 15 from both sides of the ditch and five from the ditch) at Drained, Res 5 and Res 10 sites. Only the lowest peat surfaces of each sampling unit were leveled at Pristine sites giving altogether 20 leveling values for each Pristine site.

We converted the measurements of water table depth in each well to the absolute level of water table throughout the site by subtracting the measured water table depths from the level of peat surface at the location of each well. Most peatlands have a naturally sloping surface and, consequently, a sloping water table. Since we were interested in the effects of drainage and restoration on within-site variation in the water table level, the variation in water table level caused by the ditch needed to be separated from the variation caused by the natural slope in the water table. Therefore, we corrected the water table level calculated for each sampling unit in two directions (coaxial and perpendicular to the ditch) to gain comparable horizontal values of water table level throughout the site. To correct for the natural slope coaxial to the ditch we firstly calculated the average level of the 
lowest peat surface at the transects furthest away from each other in the direction coaxial to the ditch. To exclude the possible effect of surface subsidence near the ditches, only the values of the levelings 10 and $15 \mathrm{~m}$ from the ditch at both sides of the ditch were used. Secondly, the difference in elevation (in $\mathrm{cm}$ ) between the first and the last transects was calculated and divided by the distance between the transects $(20 \mathrm{~m})$ to gain the difference in elevation per meter of distance. Thirdly, we calculated a correction term for each transect by multiplying the difference in elevation per meter by the distance to the first transect. The water table levels in each well were then corrected by adding the correction term to the water table levels. For example, the water table level in the wells with a five meter distance from the first transect was corrected by dividing the total difference in the elevation by 20 , multiplying the product by five and adding the resulted correction term to the original water table levels. The water table levels were thereafter corrected similarly for the natural slope perpendicular to the ditch. However, instead of using the levelings from the transects furthest away from each other in direction coaxial to ditch (as described above), the levelings at $15 \mathrm{~m}$ distance from the ditch at both sides of the ditch (altogether 10 values) were used. At pristine sites, the correction was calculated using the values at the opposite sides of the sampling unit grid.

\subsection{Water sampling for chemical analyses}

To study changes in water chemistry, 32-mm diameter polypropylene pipe wells with 2 $\mathrm{mm}$ slits and polypropylene filter gauges were laid at study sites (Fig. 1). At the Drained and restored sites, three wells with 10-m intervals to each other were laid to the distance of $15 \mathrm{~m}$ from the ditch (sampling location "Peat strip"; Fig. 1). Additionally, one and three more wells were laid into the ditch at the Drained and restored sites (sampling location "Ditch"; Fig. 1), respectively. Altogether three wells were laid in central parts of the sampling grid at Pristine sites (Fig. 1). The $100 \mathrm{~cm}$ long wells penetrated to $90 \mathrm{~cm}$ depth into peat. Water samples were collected in August 2007 with a plastic vacuum pump in 250-ml plastic bottles and kept cool with ice coolers during the transport. For analyses, the samples were divided in seven categories (subgroups) according to their management status and sampling location: (1) Drained ditch, 2) Drained peat strip, 3) Res 5 ditch, 4) Res 5 peat strip, 5) Res 10 ditch, 6) Res 10 peat strip, 7) Pristine).

We analysed $\mathrm{pH}$, electrical conductivity $(\mathrm{EC})$, redox potential $\left(\mathrm{E}_{\mathrm{h}}\right)$ and concentrations of $\mathrm{Ca}, \mathrm{Fe}, \mathrm{Na}, \mathrm{N}, \mathrm{P}$, and dissolved organic carbon (DOC) from the water samples. Measurements of $\mathrm{pH}, \mathrm{EC}$ and $\mathrm{E}_{\mathrm{h} 7}$ were conducted after 2 to 5 hours of collection using a Consort SP50X meter and electrodes SP10B, SK10T, SP50X. Temperature compensation was automated to reference temperature $+25^{\circ} \mathrm{C}$. The samples were then stored in $+4^{\circ} \mathrm{C}$, dark before analyses. The concentrations of cations $(\mathrm{Ca}, \mathrm{Fe}, \mathrm{Na})$ and total organic carbon (TOC, hereafter referred to as DOC due to filtration) were analyzed from all collected samples after filtration with $0.45 \mu \mathrm{m}$ membrane filters with PerkinElmer Optima 4300 DV inductively coupled plasma optical emission spectrometer and Shimadzu TOC-5000 analyzer, respectively. The analyses of cations were performed in the laboratory of Inorganic and Analytic Chemistry of the University of Jyväskylä and the analyses of N, P and DOC in the Ecology Research Institute laboratory of the University of Eastern Finland, Joensuu. The concentrations of $\mathrm{N}$ and $\mathrm{P}$ were analyzed from two samples per site (one 
sample per sampling location) except for three Drained sites for which only samples from strips were analyzed, and Pristine sites for which only one sample per site was analyzed.

\subsection{Data analysis}

The focus of our study is in the effects of degradation (drainage) and recovery (restoration) on different hydrological aspects (water table level, water chemistry) of peatlands. However, for the clarity of presentation, the analytical methods and results are divided according to hydrological aspect studied.

\subsubsection{Water table level}

To study the effects of drainage and restoration on water table level, we analyzed the effect of management status (Pristine, Drained, Res 5, Res 10) and distance from the ditch on the water table level with linear mixed model analysis. The analysis was chosen because it allows the use of data with unequal variances and data from a nested hierarchy like ours with several sampling units and wells with different distances to ditch within each site. Management status, distance from the ditch $(0,5,10,15 \mathrm{~m})$, and their interaction were used as fixed factors in the analyses. Site identity, distance from the ditch (subject to site) and month (subject to site) were used as random factors. Water table differences between different management statuses and between different distances from the ditch within each management status category were examined with Fisher's Least Significant Difference (LSD) tests. Two sites (one from Res 5 and another from Pristine) were excluded from the water table level analyses due to insufficient leveling results. Average over values for two wells per sampling unit was calculated before the analysis.

\subsubsection{Water chemistry}

We needed altogether four analytical steps to study changes in water chemistry. First, we analyzed if drainage and restoration had affected water chemistry in general. We measured a large number of possibly correlated water chemical variables, and therefore we performed a principal component analysis (PCA). PCA reduces the dimensionality of the data set, retains as much of the variation as possible and defines the most important principal components (PCs) of the data. To see if management status had an overall effect on water chemistry, we calculated Euclidean distances (ED) between samples belonging to different subgroups (1) Drained ditch, 2) Drained peat strip, 3) Res 5 ditch, 4) Res 5 peat strip, 5) Res 10 ditch, 6) Res 10 peat strip, 7) Pristine) in the three dimensional PCA solution and tested the differences with MRPP (Multi-Response Permutation Procedures). Three first PCs were selected for comparisons since they showed a significant or nearly significant difference from random solution while for rest of the components the p-value of permutations was 1.000 (Table 3 ).

Secondly, to study if restoration had, in addition to having a general impact on water chemistry, induced a change of overall water chemistry towards original chemistry, we compared the average ED between Pristine and other sites separately for ditches and peat strips. This was done by calculating an average ED between each Pristine sample and other subgroups (for each Pristine sample average over all EDs between the sample and 
samples in a certain subgroup). The differences between Drained and restored samples in EDs to Pristine samples were tested with independent samples t-test.

Thirdly, we assessed how drainage and restoration affected pore water chemistry. For that we interpreted the correlations between water chemical variables used in the PCA $(\mathrm{pH}$, EC, Ca, Na, Fe, P, N, DOC) and most important water chemical gradients PC1-PC3 (Table 3). To study how the changes in water chemistry induced by drainage and restoration were related to PCs or more detailed single water chemical variables ( $\mathrm{pH}, \mathrm{EC}, \mathrm{Ca}, \mathrm{Na}, \mathrm{Fe}$, $\mathrm{P}, \mathrm{N}, \mathrm{DOC}, \mathrm{E}_{\mathrm{h} 7}$ ), we calculated the average value of each PC and chemical variable for each site. The overall effect of management status was tested with ANOVA and differences between management statuses were examined with LSD tests.

Fourthly, to assess the within-site variation in water chemistry we determined whether there were differences in water chemistry between ditches and peat strips at Drained and restored sites. For that we analyzed the effects of management status and sampling location (ditch/peat strip) on PCs and water chemical variables with repeated measures ANOVA using sampling location as a within-subject factor and management status as a between-subject variable. Pristine sites were excluded from the analysis because they did not have the same sampling location variable due to absence of ditches. Differences between ditches and peat strips for each management status were examined with LSD tests.

Averages of values of analyzed variables for each site were calculated for ditches and peat strips before the analyses. Because $\mathrm{pH}$ (hydrogen ion concentration) affects water conductivity, EC was corrected by subtracting the conductivity of $\mathrm{H}^{+}$in each sample from EC detected from samples. Original redox potential $\left(E_{h 7}\right)$ values were also $\mathrm{pH}$ corrected according to calculation $\mathrm{E}_{\mathrm{h} 7}=\mathrm{E}_{\mathrm{h}}-59^{*}(7-\mathrm{pH})$ where $\mathrm{E}_{\mathrm{h}}$ is the redox potential measurement in the field. Furthermore, the meter readings were corrected for the $\mathrm{Ag} / \mathrm{AgCl}$ reference electrode (Consort SP50X) by adding $200 \mathrm{mV}$. Since we only analyzed N and P concentrations from ditches at three drained sites we excluded other samples collected from ditches at Drained sites from PCA and subsequent analyses based on PCA scores.

Linear mixed models, ANOVA, LSD comparisons, t-tests and repeated measures ANOVA were calculated with IBM SPSS statistics 20.0 and PCA and MRPP with PC-Ord 5.33 (McCune and Mefford 2006).

\section{Results}

\subsection{Water table level}

Management status and distance from the ditch had a significant effect on the average seasonal water table level (Table 1). Pairwise comparisons showed a lower water table level for Drained than for Pristine, Res 5 and Res 10, whereas there were no differences between Pristine and either of the restored groups (Table 2, Fig. 2). The significant management status by distance interaction effect suggests that the effect of management status was different at different distances from the ditch (Table 1). There were no differences in water table level between different distances from the ditches at Pristine or 
at Res 5 sites (LSD comparison, $\mathrm{df}=96, \mathrm{p}>0.271$ for all), but water table level at Drained sites differed between all distances from the ditch (LSD comparison, $\mathrm{df}=96, \mathrm{p}<0.001$ for all, Fig. 2) except between the 10-m and 15-m distances (LSD comparison, $\mathrm{df}=96, \mathrm{p}=$ 0.303). At Res 10 sites there seemed to be a tendency for lower water table level at the $0-\mathrm{m}$ than at the 10-m and 15-m distances from the ditch (LSD comparison, $\mathrm{df}=96, \mathrm{p}<0.019$ for both), whereas there were no differences between other distances (LSD comparison, $\mathrm{df}=$ $96, \mathrm{p}>0.099$ for all). Thus, the water table level seems to have lowered in the infilled ditches 10 years after the restoration (Fig. 2).

\subsection{Pore water chemistry}

The PC1 explained $33 \%$ of variation and correlated most strongly with $\mathrm{pH}, \mathrm{Ca}$ and EC (Table 3), representing therefore the minerogenic influence in pore water. The PC2 explained $27 \%$ of variation and correlated most strongly with concentrations of N, P and DOC (Table 3). Consequently, PC2 is interpreted to represent the release of nutrients from peat matrix. The PC3 explained an additional $16 \%$ of variation and correlated with concentrations of Fe and Na. Unlike the first two PCs, PC3 was not quite statistically significant (Table 3).

The PCA and subsequent MRPP analysis showed a significant difference between Pristine and Drained sites (Fig. 3, Table 4). Additionally, there was a difference between Pristine and Res 5 and between Pristine and Res 10 in the cases of both ditches and peat strips (Fig. 3, Table 4). However, for both ditches and peat strips the pore water chemistry of Res 10 was closer to Pristine chemistry than the chemistry of Drained (independent samples t-test between Drained and Res 10, equal variances assumed; ditches: $\mathrm{t}=3.005, \mathrm{df}=18, \mathrm{p}=$ 0.008; peat strips: $\mathrm{t}=2.747, \mathrm{df}=18, \mathrm{p}=0.013$; Fig. 3 ). Although the ED to Pristine sites was smaller for Res 5 than for Drained, the differences were not statistically significant (independent samples t-test between drained and Res 5, equal variances assumed; ditches: $\mathrm{t}=1.059, \mathrm{df}=18, \mathrm{p}=0.303$; peat strips: $\mathrm{t}=1.850, \mathrm{df}=18, \mathrm{p}=0.081$; Fig. 3 ).

Examination of the PCs and individual chemical variables with ANOVA showed that management status had a significant overall effect on PC2 and on the concentrations of $\mathrm{Ca}$, $\mathrm{N}$ and $\mathrm{P}$ (Table 5). Differences were indicated also for EC, $\mathrm{pH}$ and DOC (Table 5). Pairwise comparisons showed that drainage clearly raised the overall values for $\mathrm{Ca}$ and $\mathrm{pH}$ when compared to pristine conditions (Table 6, Fig. 4). Furthermore, there was an apparent tendency towards that for DOC and EC also. Despite apparently higher $\mathrm{N}$ and $\mathrm{P}$ concentrations at peat strips when compared to pristine sites, the overall effect of drainage was not statistically significant due to low concentrations in ditch water (Fig. 4). Average $\mathrm{Ca}$ and $\mathrm{pH}$ decreased already five years after restoration to pristine level but for Ca there seemed to be a slight difference again between Pristine and Res 10 (Table 6, Fig 4). Also DOC decreased after restoration when compared to Drained sites. Whereas the average DOC was still slightly higher in Res 10 than Pristine, the difference between the groups was not statistically significant (Table 6, Fig 4). The average values of PC2, N and P were clearly higher for Res 5 than Pristine (Table 6, Fig 4). Furthermore, a statistically significant but less clear difference was found between Res 5 and Drained (Table 6, Fig. 4). There were no differences between Drained and Res 10 for PC2, N and P (Table 6, Fig 4). N and P seemed to, furthermore, be lower for Res 10 than for Res 5 . Whereas the average P was still 
slightly higher in Res 10 than Pristine, the difference between the groups was not statistically significant (Table 6, Fig 4). Restoration did not affect the average EC raised by drainage and, in fact, the average EC rise after drainage was largely driven by high ditch water EC (Table 6, Fig 4). There was a tendency towards lower Na concentration for Res 10 than Drained, but we did not find a difference between the Pristine and any other management status (Table 6, Fig 4). There was a clear tendency towards higher average Fe concentration at Res 10 than at Pristine, but there were no differences between Drained and Res 5 or between Drained and Res 10 (Table 6, Fig 4). For PC1 and $E_{\mathrm{h} 7}$ there was a slight tendency towards a difference between Drained and Pristine, but neither Res 5 nor Res 10 differed from Pristine (Table 6, Fig 4). Eh7 seemed to be, furthermore, lower at Res 5 and Res 10 than Drained (Table 6, Fig 4).

According to the PCA and MRPP, the overall water chemistry at Drained sites differed between ditches and strips but there were no differences between ditches and strips for either Res 5 or Res 10 (Table 4, Fig 3). A significant sampling location effect in the repeated measures ANOVA performed without Pristine sites suggests an overall clear difference between the samples collected from ditches and peat strips for DOC and $\mathrm{pH}$, and a clear tendency towards a difference for PC1 (Table 7, Fig. 4). Furthermore, a significant sampling location $\times$ management status interaction suggests that the effect differed between Drained, Res 5 and Res 10 for PC1, N, DOC and pH (Table 7, Fig. 4). Pairwise comparisons showed that at the Drained sites values for PC1 and $\mathrm{pH}$ were clearly higher in the samples collected from the ditches than from the peat strips and, that there was an apparent tendency towards such a difference for EC as well (Table 8). In contrast, PC1 and DOC were lower in the ditches than in the peat strips (Table 8, Fig 4). However, we found no differences for PC1, pH, EC and DOC between the ditches and peat strips at Res 5 and Res 10 (Tables 7 and 8, Fig. 4). N was higher in the ditches than in peat strips for Res 5, but there was no difference between the ditches and peat strips for Drained and Res 10 (Table 8, Fig. 4). Similarly, PC3 values differed between ditches and strips at Res 5 but no difference could be seen at Res 10 or Drained (Table 8, Fig. 4).

\section{Discussion}

We show that significant lowering of the average water table level by peatland drainage is sustained for decades and that the draw down remains largest near the ditches. The natural pattern of high and even water table level was regained five years after restoration but increased within-site unevenness of the water table level was observed again 10 years after restoration. Also drainage-induced changes in water chemistry were significant still several decades after drainage. Overall elevation of $\mathrm{pH}$ and $\mathrm{EC}$ as well as increased average concentrations of $\mathrm{Ca}$ and DOC were observed at Drained sites when compared to Pristine, but there were large differences between the samples collected from ditches and adjacent peat strips. For example, increased $\mathrm{pH}$ and EC after drainage were driven by significantly higher values in ditches when compared to peat strips. Furthermore, despite higher $\mathrm{N}$ and $\mathrm{P}$ concentrations at peat strips, the overall effect of drainage when compared to the concentrations at Pristine sites was not significant due to low concentrations in ditch water. Restoration induced a recovery of pore water chemistry towards pristine chemistry. Especially the water chemical factors related to minerogenic influence of pore water had recovered and for $\mathrm{Ca}, \mathrm{pH}, \mathrm{DOC}, \mathrm{E}_{\mathrm{h}}$ values close to pristine levels were reached during the 
first few years after restoration. Restoration could also remove most of the water chemical differences (especially related to $\mathrm{pH}$ and DOC) between ditches and peat strips. The concentrations of $\mathrm{N}$ (especially in the ditches) and $\mathrm{P}$ increased in pore water five years after restoration, decreasing again 10 years after restoration. Fe showed an increasing pattern after restoration especially in the filled ditches.

The greatest hydrological change caused by drainage is the decadal drawdown of water table observed in our study. This drawdown affects not only peatland structures, such as above and below ground communities (Laine et al. 1995; Jaatinen et al. 2007), but also ecosystem functions such as soil respiration, nutrient circulation and accumulation of peat and C (Braekke 1987; Martikainen et al. 1995; Mäkiranta et al. 2009; Kareksela et al. 2014). As the average water table level could be re-established and maintained for 10 years, restoration of studied peatlands was successful in regaining the single most important condition needed for further recovery of ecosystem. Together with water table level, changes of pore water chemistry may influence peatland community composition and peatland functions (Tahvanainen et al. 2002; Price et al. 2005; Bragazza et al. 2005). Our results show that differences between Pristine and Drained sites in chemistry are significant still after several decades. However, the recovery of overall pore water chemistry towards targeted pristine conditions after restoration is promising and may act to promote e.g. the recovery of plant communities (Haapalehto et al. 2011; Laine et al. 2011; Hedberg et al. 2012).

In addition to clear within-site differences in water table level after drainage, we expected to see water chemical differences between samples from ditches and adjacent peat strips in Drained sites. The flow of mineral-rich water from catchment is directed along the artificial flow paths formed by ditches, and hence mineral element concentrations and $\mathrm{pH}$ are often higher in ditches than in peat strips. Secondly, increased DOC was expected in peat strips when compared to ditches due to potentially higher DOC production and diminished flushing rate allowing DOC to accumulate in pore water in peat strips (Tahvanainen et al. 2002). Such differences were, indeed, evident in our data.

Even slight changes in water table level or water chemistry may affect the development of peatland ecosystems (Tahvanainen 2011). Restoration should, therefore, aim to eliminate the unnatural within-site hydrological differences and artificial water flow paths. After the initial recovery of even within-site water table level five years after restoration, the water table level seemed to have lowered at infilled ditches when compared to surrounding areas 10 years after restoration. Such a lowering might be due to erosion of dams and ditch-fillings resulting in redevelopment of flow paths along the infilled ditches and the subsided areas close to them. With time, such development could lead to insufficient rewetting of areas further away from the ditches. This, in turn, could hamper the recovery of peatland species communities (Haapalehto et al. 2011; Hedberg et al. 2012). Similarly to the Drained sites, the concentration of water flow along the infilled ditches should, most likely, result in increased mineral concentrations and decreased DOC at the infilled ditch areas when compared to pore water elsewhere. We did not find such pore water differences between the infilled ditches and peat strips at Res 5 and Res 10 sites, however. This suggests that the slightly decreased water table level in the infilled ditches would not 
have influenced the hydrological recovery of the restored sites. We find, however, that the increased within-site differences in water table level may hamper the recovery of hydrology in the future, and the possible long-term deterioration of ditch blocking structures should not be ignored by restoration practitioners.

The major nutrients $\mathrm{N}$ and $\mathrm{P}$ are generally scarce in the studied peatlands and they are effectively taken up by living organisms (Silvan et al. 2003, 2004b). Large hydrological disturbances such as drainage and restoration result in turnover of species and provide new substrate for decomposers. Subsequently, increased $\mathrm{N}$ in pore water has been observed a few years after drainage (Prévost et al. 1999). We did not find general increase of $\mathrm{N}$ and $\mathrm{P}$ in drained peatlands, due to lower levels observed in ditch water, but pore water concentrations at Drained sites were many-fold higher compared to pristine pore water still decades after drainage (Fig. 4). At restored sites, we found an increase of $\mathrm{N}$ and $P$ similar to those observed earlier in pore water of rewetted temperate alkaline fens (Zak and Gelbrecht 2007; Zak et al. 2010) and outflow waters of more acidic boreal peatlands (Koskinen et al. 2011). Such an increase may be due to increased amounts of redox sensitive substances and, parallel to the effects of drainage, enhanced availability of decomposable organic matter in the upper highly decomposed peat horizon (Zak and Gelbrecht 2007). Whereas increased P concentrations were observed for both ditches and strips five years after restoration, significant increase of $\mathrm{N}$ was found only at the infilled ditches. Ground level vegetation and trees are very effective in retaining $\mathrm{N}$ after altered nutrient conditions in the studied type of peatlands (Silvan et al. 2004b; Vikman et al. 2010). Abundance of Eriophorum vaginatum, a key species in terms of nutrient immobilization in boreal peatlands (Silvan et al. 2004a), and growth of tree saplings increase significantly for a few years after restoration (Kuuluvainen et al. 2002; Haapalehto et al. 2011) especially when restoration measures include removal of tree stand (Hedberg et al. 2012). Increased $\mathrm{N}$ concentration in the infilled ditches may therefore be related to higher physical disturbance during restoration followed by slower recovery of vegetation after restoration in ditches when compared to peat strips.

Increased release of nutrients after restoration is suspected to cause eutrophication of downstream waters especially in nutrient rich wetlands (Niedermeier and Robinson 2007, 2009; Zak et al. 2008). Like earlier results focusing on runoff waters from similar nutrient poor peatlands (Koskinen et al. 2011), we found the highest post-restoration pore water $\mathrm{P}$ concentrations approximately five years after rewetting. Furthermore, we found a decline close to the pristine level at the sites restored 10 years ago. In contrast to high $\mathrm{P}$ mobilization over decades taking most likely place in rewetted calcareous fens with agricultural history (Zak et al. 2008), our results suggest that the risk of eutrophication of downstream waters diminishes after five to ten years after restoration of nutrient-poor peatlands drained for forestry. The peatlands studied by Koskinen et al. (2011) were of similar nutrient poor type and also located in Southern Finland. Similar temporal P release pattern observed in pore water concentrations (our study) and in outflow water (Koskinen et al. 2011) after restoration suggest that pore water measurements, which are often much easier and cheaper than outflow monitoring, could provide a proxy for the estimation of nutrient outflux patterns after restoration. The quantification of fluvial fluxes would, however, require discharge monitoring. 
The effects of drainage on DOC have been controversial for a long time (see review by Holden et al. 2004). Recent studies have found increased leaching and pore water concentrations of DOC soon after excavation of ditches (Wallage et al. 2006; Strack et al. 2008) and drainage has been suggested to increase leaching of DOC to downstream watercourses (Huotari et al. 2013). The increased pore water concentrations may be due to elevated net DOC production under lower water table conditions driven by increased decomposable biomass after vegetation change and larger water table fluctuations (Wallage et al. 2006; Strack et al. 2008). It is surprising, therefore, that drainage has not been clearly connected to increased DOC concentrations and export in long-term monitoring of downstream waters (Lepistö et al. 2008; Sarkkola et al. 2009; Rantakari et al. 2010; Räike et al. 2012). The effect of restoration on fluvial carbon export is, perhaps, even more contradictory. Increased TOC release especially at nutrient rich sites (Koskinen et al. 2011) and increased TOC and DOC in blocked ditches shortly after restoration (Worrall et al. 2007; Gibson et al. 2009; Wilson et al. 2011a) have been observed. In parallel, severe natural droughts followed by natural rewetting could destabilize $C$ stocks causing DOC losses to downstream waters (Fenner and Freeman 2011). In contrast, decreased DOC concentration in soil water perhaps due to increased flushing of DOC from upper peat layers in short term (Wallage et al. 2006) and decreased decomposition (Höll et al. 2009) decades after restoration have been found. These apparent controversies may partly reflect methodological differences arising from e.g. whether ditch or pore water concentrations were studied and whether discharge rates were considered or not (Wilson et al. 2011a). Furthermore, large differences in time-scale of studies (from a couple of years to decades), different focal peatland types (blanket bogs, fens, boreal Sphagnum peatlands) and difficulties in separating the effects of drainage or restoration from other land-use within the studied catchments complicate comparisons between studies.

Here, we took a snapshot on DOC concentrations of originally similar boreal Sphagnum peatlands decades after drainage. Ditch water DOC at Drained sites was close to the pore water DOC of Pristine. When interpreting the results one should, however, notice that the sampled ditches were not systematically selected to drain entire peatlands. It is therefore likely that a large share of DOC produced in studied drained peatlands is not present in the sampled ditches, and our ditch water DOC estimates are not comparable to studies reporting effects of drainage on DOC outflux in runoff. Instead, it is more relevant to compare pore water from Pristine sites to the pore water from peat strips at Drained sites. Such a comparison describing the impact of drainage on pore water DOC (within the peat where the actual production and decomposition of DOC take place) shows 1.6 times (36 $\mathrm{mg} / \mathrm{l}$ ) higher DOC for Drained than Pristine on average. DOC may be flushed to downstream aquatic ecosystems (Worrall et al. 2002) during peak flow periods, where the increased DOC loading can alter physical and chemical conditions such as acidity, light penetration and bioavailability of metals and nutrients or contribute to food webs as carbon source to microbes (Evans et al. 2005). Although it is not possible to estimate the extra DOC load due to elevated concentrations in pore water after drainage without discharge data, the order of magnitude of potential load may be approached by a simple calculation concentrating, say, in Finland where forestry-drainage has been perhaps most extensive. Assuming that the peatland sites and the snap-shot DOC concentrations 
measured here are representative of average conditions of the five million ha of drained peatlands in Finland and that annually all DOC of uppermost $30-\mathrm{cm}$ pore water layer is exported from surface peat with average water content of 0.9 (270 mm runoff), we arrive in an estimate of a capacity of Finnish peatlands to lose DOC at an increased rate of 486 $000 \mathrm{t}$ per year due to drainage. Although this is a very rough figure produced by a simplified multiplication, it can be compared e.g. with the total DOC export by Finnish rives to the Baltic Sea, estimated at $900000 \mathrm{t} \mathrm{C} \mathrm{yr}^{-1}$ (Räike et al. 2012). We do not suggest half of Finnish river DOC export would be caused by drainage of peatlands, but we point out that pore waters in surface peat strata of drained peatlands do contain excess DOC in this comparably high order of magnitude that may be exported as depending on hydrological conditions.

In contrast to increased DOC concentration due to drainage, we found a decreasing trend of DOC concentrations after restoration in both ditch and pore water, with average concentration close to pristine level 10 years after restoration. Hence, the $22 \mathrm{mg} / 1$ lower average DOC concentration 10 years post-restoration when compared to the average DOC in peat strips of Drained sites suggests that restoration could result in significant reduction in leaching of fluvial carbon from drained peatlands. Thereby, peatland restoration has the potential to improve downstream water quality in long-term. This might be especially important in heavily drained areas such as Finland where meeting the global target of restoring $15 \%$ of degraded ecosystems suggests restoring 0.75 million ha peatlands (Convention on Biological Diversity 2010). It must, however, be noted that the DOC concentration in pore water changes seasonally (Tahvanainen et al. 2003) and is dependent on peat quality (Zak and Gelbrecht 2007). Because the export of DOC depends also on discharge rates and drainage may decrease the amount of water passing through the peat matrix, it may be that some of the excess DOC observed in pore water after drainage will not be flushed to downstream waters. On the other hand, even slightly increased concentrations of DOC in ditch water may result in significantly decreased outflux of DOC due to decreased water flow from the drains after restoration (Gibson et al. 2009; Wilson et al. 2011a). Since we did not measure discharge rates and studied only one type of peatlands with nonrecurring pore water sampling, our results only describe potential mobile pools of DOC as affected by drainage and restoration.

DOC loss may approach $2 / 3$ of the annual carbon sink of boreal peatlands (Roulet $e t$ al. (2007), but see Gažovič et al. (2013) for lower estimates). The significantly increased pore water DOC after drainage may, therefore, partly explain recent studies that have found large losses of carbon from peat after decades of drainage (Simola et al. 2012; Pitkänen et al. 2013; Kareksela et al. 2014). On the other hand, rapid re-establishment of surface peat accumulation rate was recently found after peatland restoration (Kareksela et al. 2014). Together with our results this suggests the potential of restoration to recover some important components of peatland carbon cycle. Given the global importance of fluvial carbon fluxes from peatlands and the results presented here and in previous studies, DOC dynamics after drainage and restoration certainly deserve further long-term studies.

The elevated Fe concentrations at Res 5 when compared to Pristine and the tendency towards higher $\mathrm{Fe}$ in ditches than peat strips may be related to differences in redox 
conditions. Filled ditches have often small ponds and areas lying topographically lower than adjacent areas. Due to accumulation of water in these areas, anaerobic, reductive conditions would favor reduction of Fe (III) to Fe (II) increasing Fe solubility and hence elevate concentrations of $\mathrm{Fe}$ in pore water (Küsel et al. 2008). The high total Fe concentrations (and wide range of variation) in filled ditches should, thus, be connected to low redox. Indeed, while no overall difference of $\mathrm{E}_{\mathrm{h} 7}$ was found between ditches and peat strips at Res 5 and Res 10, the hypothesis is supported by a significant negative Pearson correlation $(-0.66, \mathrm{p}<0.01)$ between $\mathrm{Fe}$ and $\mathrm{E}_{\mathrm{h}}$ at restored sites suggesting that highest $\mathrm{Fe}$ was found in most reductive environments. Fe reduction is linked to circulation of $C, S, P$ and $\mathrm{N}$ in anaerobic soils and hence to several peatland functions such as methanogenesis and DOC production (Lovley 1991; Knorr 2012). Our results suggest that even though we did not observe water chemical differences between the ditches and strips in nonrecurring measurements of $\mathrm{pH}$ and DOC in restored sites, further research is needed to draw a clear picture on the behavior of Fe and the recovery of peatland functions related to pore water Fe. This is especially true, since Fe is suggested to be one key chemical component for the recovery of rewetted peatlands (Kemmers et al. 2003). In addition to affecting the biogeochemical cycles of peat it may for example hamper the establishment of specialist species after restoration (Aggenbach et al. 2013).

In conclusion, drainage for forestry has long-lasting effects on boreal peatland hydrology resulting in drawdown of water table level and substantial changes of pore water chemistry. Moreover, drainage causes increased small scale spatial variation in water table level and water chemistry within peatlands. Restoration, in contrast, recovers the water table level and initiates a gradual recovery in the pore water chemistry towards values typical to pristine peatlands. However, we observed a re-emerging drawdown of water table level at the infilled ditches lines at the sites studied 10 years after restoration. Even though we did not find evidence in pore water chemistry to show that such a drawdown would hamper further recovery of restored ecosystems, this may be an early warning sign of failure of hydrological recovery in the future. This should not be ignored by restoration practitioners and scientists responsible for monitoring the effects of restoration. While restoration has the potential to reduce leaching of DOC to downstream waters in the long term, practitioners should be prepared for excess leaching of $\mathrm{N}$ and $\mathrm{P}$ from boreal Sphagnum peatlands for at least five years after restoration.

\section{Acknowledgements}

Thanks to Dr. Anssi Lensu and Dr. Tarmo Ketola for their help with linear mixed models. M.Sc Riikka Juutinen and M.Sc. Santtu Kareksela helped us with data collection. Senior Scientist Tapani Sallantaus gave highly valuable comments on the manuscript. The study was financed by Maj and Tor Nessling foundation, Kone foundation and Finnish Ministry of the Environment. Metsähallitus kindly provided us with the sites to study. 


\section{References}

Aapala K., Similä M. \& Haapalehto T.O. 2009. Research and monitoring support peatland restoration in Finland. Peatlands international 1: 26-31.

Aggenbach C.J.S., Backx H., Emsens W.J., Grootjans A.P., Lamers L.P.M., Smolders A.J.P., Stuyfzand P.J., Wolejko L. \& Diggelen R. Van. 2013. Do high iron concentrations in rewetted rich fens hamper restoration? Preslia 85: 405-420.

Åström M., Aaltonen E.-K. \& Koivusaari J. 2001. Effect of ditching operations on streamwater chemistry in a boreal forested catchment. The Science of the total environment 279: 117-129.

Belyea L.R. \& Malmer N. 2004. Carbon sequestration in peatland: patterns and mechanisms of response to climate change. Global Change Biology 10: 1043-1052.

Benayas J.M.R., Newton A.C., Diaz A. \& Bullock J.M. 2009. Enhancement of Biodiversity and Ecosystem Services by Ecological Restoration: A Meta-Analysis. Science 325: 11211124.

Braekke F.H. 1987. Nutrient relationships in forest stands: Effects of drainage and fertilization on surface peat layers. Forest Ecology and Management 21: 269-284.

Bragazza L. \& Gerdol R. 1999. Hydrology, groundwater chemistry and peat chemistry in relation to habitat conditions in a mire on the South Eastern Alps of Italy. Plant Ecology 144: 243-256.

Bragazza L., Rydin H. \& Gerdol R. 2005. Multiple gradients in mire vegetation: a comparison of a Swedish and an Italian bog. Plant Ecology 177: 223-236.

Convention on Biological Diversity. 2010. Strategic Plan for Biodiversity 2011-2020. Conference of the Parties, Nagoya. Available from http://www.cbd.int/sp/ (accessed August 2013).

Dobson A.P., Bradshaw A.D. \& Baker A.J.M. 1997. Hopes for the Future: Restoration Ecology and Conservation Biology. Science 277: 515-522.

European Commission. 2011. The EU Biodiversity Strategy to 2020. http://ec.europa.eu/environment/nature/biodiversity/comm2006/2020.htm (accessed 10/2013).

Evans C.D., Monteith D.T. \& Cooper D.M. 2005. Long-term increases in surface water dissolved organic carbon: Observations, possible causes and environmental impacts. Environmental Pollution 137: 55-71.

Fenner N. \& Freeman C. 2011. Drought-induced carbon loss in peatlands. Nature Geoscience 4: 895-900.

Foley J.A., Defries R., Asner G.P., Barford C., Bonan G., Carpenter S.R., Chapin F.S., Coe M.T., Daily G.C., Gibbs H.K., Helkowski J.H., Holloway T., Howard E.A., Kucharik C.J., Monfreda C., Patz J.A., Prentice I.C., Ramankutty N. \& Snyder P.K. 2005. Global consequences of land use. Science (New York, N.Y.) 309: 570-574.

Freeman C., Fenner N., Ostle N.J., Kang H., Dowrick D.J., Reynolds B., Lock M.A., Sleep D., Hughes S. \& Hudson J. 2004. Export of dissolved organic carbon from peatlands under elevated carbon dioxide levels. Nature 430: 195-198.

Gažovič M., Forbrich I., Jager D.F., Kutzbach L., Wille C. \& Wilmking M. 2013. Hydrologydriven ecosystem respiration determines the carbon balance of a boreal peatland. Science of The Total Environment 463-464: 675-682. 
Gibson H.S., Worrall F., Burt T.P. \& Adamson J.K. 2009. DOC budgets of drained peat catchments: implications for DOC production in peat soils. Hydrological Processes 23: 1901-1911.

Haapalehto T.O., Vasander H., Jauhiainen S., Tahvanainen T. \& Kotiaho J.S. 2011. The effects of peatland restoration on water-table depth, elemental concentrations and vegetation: 10 years of changes. Restoration Ecology 19: 587-598.

Hedberg P., Kotowski W., Saetre P., Mälson K., Rydin H. \& Sundberg S. 2012. Vegetation recovery after multiple-site experimental fen restorations. Biological Conservation 147: 60-67.

Holden J. 2005. Peatland hydrology and carbon release: why small-scale process matters. Philosophical Transactions of the Royal Society A: Mathematical, Physical and Engineering Sciences 363: 2891-2913.

Holden J., Chapman P.J. \& Labadz J.C. 2004. Artificial drainage of peatlands: hydrological and hydrochemical process and wetland restoration. Progress in Physical Geography 28: 95-123.

Holden J., Wallage Z.E., Lane S.N. \& McDonald A.T. 2011. Water table dynamics in undisturbed, drained and restored blanket peat. Journal of Hydrology 402: 103-114.

Höll B.S., Fiedler S., Jungkunst H.F., Kalbitz K., Freibauer A., Drösler M. \& Stahr K. 2009. Characteristics of dissolved organic matter following 20 years of peatland restoration. Science of The Total Environment 408: 78-83.

Huotari J., Nykänen H., Forsius M. \& Arvola L. 2013. Effect of catchment characteristics on aquatic carbon export from a boreal catchment and its importance in regional carbon cycling. Global Change Biology 19: 3607-3620.

Jaatinen K., Fritze H., Laine J. \& Laiho R. 2007. Effects of short- and long-term water-level drawdown on the populations and activity of aerobic decomposers in a boreal peatland. Global Change Biology 13: 491-510.

Johnson E.A. \& Miyanishi K. 2008. Testing the assumptions of chronosequences in succession. Ecology Letters 11: 419-431.

Jungkunst H.F. \& Fiedler S. 2007. Latitudinal differentiated water table control of carbon dioxide, methane and nitrous oxide fluxes from hydromorphic soils: feedbacks to climate change. Global Change Biology 13: 2668-2683.

Kareksela S., Haapalehto T.O., Juutinen R., Matilainen R., Tahvanainen T. \& Kotiaho J.S. 2014. Fighting severe carbon loss of degraded peatlands by jump-starting the original ecosystem functions with ecological restoration. in revision.

Kemmers R.H., Delft S.P.J. van \& Jansen P.C. 2003. Iron and sulphate as possible key factors in the restoration ecology of rich fens in discharge areas. Wetlands Ecology and Management 11: 367-381.

Klimkowska A., Diggelen R. Van, Grootjans A.P. \& Kotowski W. 2010. Prospects for fen meadow restoration on severely degraded fens. Perspectives in Plant Ecology, Evolution and Systematics 12: 245-255.

Knorr K.-H. 2012. DOC-dynamics in a small headwater catchment as driven by redox fluctuations and hydrological flow paths - are DOC exports mediated by iron reduction/oxidation cycles? Biogeosciences 9: 12951-12984.

Konar M., Jason Todd M., Muneepeerakul R., Rinaldo A. \& Rodriguez-Iturbe I. 2013. Hydrology as a driver of biodiversity: Controls on carrying capacity, niche formation, and dispersal. Advances in Water Resources 51: 317-325. 
Koskinen M., Sallantaus T. \& Vasander H. 2011. Post-restoration development of organic carbon and nutrient leaching from two ecohydrologically different peatland sites. Ecological Engineering 37: 1008-1016.

Kuuluvainen T., Aapala K., Ahlroth P., Kuusinen M., Lindholm T., Sallantaus T., Siitonen J. \& Tukia H. 2002. Principles of Ecological Restoration of Boreal Forested Ecosystems: Finland as an Example. Silva Fennica 36(1): 409-422.

Küsel K., Blöthe M., Schulz D., Reiche M. \& Drake H.L. 2008. Microbial reduction of iron and porewater biogeochemistry in acidic peatlands. Biogeosciences 5: 1537-1549.

Laine A.M., Leppälä M., Tarvainen O., Päätalo M.-L., Seppänen R. \& Tolvanen A. 2011. Restoration of managed pine fens: effect on hydrology and vegetation. Applied Vegetation Science 14: 340-349.

Laine J. \& Vanha-Majamaa I. 1992. Vegetation ecology along a trophic gradient on drained pine mires in southern Finland. Annales Botanici Fennici 29: 213-233.

Laine J., Vasander H. \& Laiho R. 1995. Long-Term Effects of Water Level Drawdown on the Vegetation of Drained Pine Mires in Southern Finland. Journal of Applied Ecology 32: 785-802.

Lappalainen E. 1996. General review on world peatland and peat resources. In: Lappalainen E. (ed.), Global peat resources, International Peat Society, Jyväskylä, Finland, pp. 53-56.

Lepistö A., Kortelainen P. \& Mattsson T. 2008. Increased organic C and N leaching in a northern boreal river basin in Finland. Global Biogeochemical Cycles 22: - GB3029.

Lovley D.R. 1991. Dissimilatory Fe(III) and Mn(IV) reduction. Microbiological Reviews 55(2): 259-287.

Mäkiranta P., Laiho R., Fritze H., Hytönen J., Laine J. \& Minkkinen K. 2009. Indirect regulation of heterotrophic peat soil respiration by water level via microbial community structure and temperature sensitivity. Soil Biology and Biochemistry 41: 695-703.

Martikainen P.J., Nykänen H., Alm J. \& Silvola J. 1995. Change in fluxes of carbon dioxide, methane and nitrous oxide due to forest drainage of mire sites of different trophy. Plant and Soil 168-169: 571-577.

McCune B. \& Mefford M.J. 2006. PC-ORD. Multivariate Analysis of Ecological Data. Version 5.33. . MjM Software, Gleneden Beach, Oregon, USA.

Millennium Ecosystem Assessment. 2005. Ecosystems and Human Wellbeing: Synthesis. Island Press, Washington, DC.

Moore S., Evans C.D., Page S.E., Garnett M.H., Jones T.G., Freeman C., Hooijer A., Wiltshire A.J., Limin S.H. \& Gauci V. 2013. Deep instability of deforested tropical peatlands revealed by fluvial organic carbon fluxes. Nature 493: 660-663.

Moore T.R. \& Knowles R. 1989. The influence of water table levels on methane and carbon dioxide emissions from peat soils. Canadian Journal of Soil Science 69: 33-38.

Moreno-Mateos D., Power M.E., Comin F.A. \& Yockteng R. 2012. Structural and Functional Loss in Restored Wetland Ecosystems. PLoS Biol 10: e1001247.

Niedermeier A. \& Robinson J.S. 2007. Hydrological controls on soil redox dynamics in a peat-based, restored wetland. Geoderma 137: 318-326.

Niedermeier A. \& Robinson J.S. 2009. Phosphorus dynamics in the ditch system of a restored peat wetland. Agriculture, Ecosystems \& Environment 131: 161-169. 
Pitkänen A., Turunen J., Tahvanainen T. \& Simola H. 2013. Carbon storage change on a partially forestry-drained boreal mire determined through peat column inventories. Boreal Environment Research 18: 223-234.

Prévost M., Plamondon A.P. \& Belleau P. 1999. Effects of drainage of a forested peatland on water quality and quantity. Journal of Hydrology 214: 130-143.

Price J.S., Branfireun B.A., Michael Waddington J. \& Devito K.J. 2005. Advances in Canadian wetland hydrology, 1999-2003. Hydrological Processes 19: 201-214.

Price J.S., Heathwaite A.L. \& Baird A.J. 2003. Hydrological processes in abandoned and restored peatlands: An overview of management approaches. Wetlands Ecology and Management 11: 65-83.

Räike A., Kortelainen P., Mattsson T. \& Thomas D.N. 2012. 36 year trends in dissolved organic carbon export from Finnish rivers to the Baltic Sea. Science of The Total Environment 435-436: 188-201.

Rantakari M., Mattsson T., Kortelainen P., Piirainen S., Finér L. \& Ahtiainen M. 2010. Organic and inorganic carbon concentrations and fluxes from managed and unmanaged boreal first-order catchments. Science of The Total Environment 408: 16491658.

Roulet N.T., Lafleur P.M., Richard P.J.H., Moore T.R., Humphreys E.R. \& Bubier J. 2007. Contemporary carbon balance and late Holocene carbon accumulation in a northern peatland. Global Change Biology 13: 397-411.

Sarkkola S., Koivusalo H., Laurén A., Kortelainen P., Mattsson T., Palviainen M., Piirainen S., Starr M. \& Finér L. 2009. Trends in hydrometeorological conditions and stream water organic carbon in boreal forested catchments. Science of the Total Environment 408: 92-101.

Schaaf S. van der. 2012. Subsidence in bogs. The Finnish Environment 38: 295-311.

Schimelpfenig D.W., Cooper D.J. \& Chimner R.A. 2013. Effectiveness of Ditch Blockage for Restoring Hydrologic and Soil Processes in Mountain Peatlands. Restoration Ecology; DOI: $10.1111 /$ rec.12053.

Silvan N., Tuittila E.-S., Vasander H. \& Laine J. 2004a. Eriophorum vaginatum plays major role in nutrient immobilization in boreal peatlands. Annales Botanici Fennici 41: 189_ 199.

Silvan N., Vasander H., Karsisto M. \& Laine J. 2003. Microbial immobilisation of added nitrogen and phosphorus in constructed wetland buffer. Applied Soil Ecology 24: 143149.

Silvan N., Vasander H. \& Laine J. 2004b. Vegetation is the main factor in nutrient retention in a constructed wetland buffer. Plant and Soil 258: 179-187.

Simola H., Pitkänen A. \& Turunen J. 2012. Carbon loss in drained forestry peatlands in Finland, estimated by re-sampling peatlands surveyed in the 1980s. European Journal of Soil Science 63(6): 798-807.

Society for Ecological Restoration International. 2004. The SER International Primer on Ecological Restoration Science \& Policy Working Group (Version 2). Society for Ecological Restoration International.

Strack M. (ed ). 2008. Peatlands and Climate Change. International Peat Society, Jyväskylä, Finland. 
Strack M., Waddington J.M., Bourbonniere R.A., Buckton E.L., Shaw K., Whittington P. \& Price J.S. 2008. Effect of water table drawdown on peatland dissolved organic carbon export and dynamics. Hydrological Processes 22: 3373-3385.

Suding K.N. 2011. Toward an Era of Restoration in Ecology: Successes, Failures, and Opportunities Ahead. Annual Review of Ecology Evolution and Systematics 42: 465-487.

Tahvanainen T. 2011. Abrupt ombrotrophication of a boreal aapa mire triggered by hydrological disturbance in the catchment. Journal of Ecology 99: 404-415.

Tahvanainen T., Sallantaus T. \& Heikkilä R. 2003. Seasonal variation of water chemical gradients in three boreal fens. Annales Botanici Fennici 40: 345-355.

Tahvanainen T., Sallantaus T., Heikkilä R. \& Tolonen K. 2002. Spatial variation of mire surface water chemistry and vegetation in northeastern Finland. Annales Botanici Fennici 39: 235-251.

Tanneberger F. \& Wichtmann W. (eds). 2011. Carbon credits from peatland rewetting. Climate biodiversity - land use. Schweizerbart Science Publishers, Stuttgart, Germany.

Tranvik L.J. \& Jansson M. 2002. Climate change (Communication arising): Terrestrial export of organic carbon. Nature 415: 861-862.

Vasander H., Tuittila E.-S., Lode E., Lundin L., Ilomets M., Sallantaus T., Heikkilä R., Pitkänen M.-L. \& Laine J. 2003. Status and restoration of peatlands in northern Europe. Wetlands Ecology and Management 11: 51-63.

Vikman A., Sarkkola S., Koivusalo H., Sallantaus T., Laine J., Silvan N., Nousiainen H. \& Nieminen M. 2010. Nitrogen retention by peatland buffer areas at six forested catchments in southern and central Finland. Hydrobiologia 641: 171-183.

Wallage Z.E., Holden J. \& McDonald A.T. 2006. Drain blocking: An effective treatment for reducing dissolved organic carbon loss and water discolouration in a drained peatland. Science of The Total Environment 367: 811-821.

Wilson L., Wilson J., Holden J., Johnstone I., Armstrong A. \& Morris M. 2011a. Ditch blocking, water chemistry and organic carbon flux: Evidence that blanket bog restoration reduces erosion and fluvial carbon loss. Science of The Total Environment 409: 2010-2018.

Wilson L., Wilson J., Holden J., Johnstone I., Armstrong A. \& Morris M. 2011b. The impact of drain blocking on an upland blanket bog during storm and drought events, and the importance of sampling-scale. Journal of Hydrology 404: 198-208.

Worrall F., Armstrong A. \& Holden J. 2007. Short-term impact of peat drain-blocking on water colour, dissolved organic carbon concentration, and water table depth. Journal of Hydrology 337: 315-325.

Worrall F., Burt T.P., Jaeban R.Y., Warburton J. \& Shedden R. 2002. Release of dissolved organic carbon from upland peat. Hydrological Processes 16: 3487-3504.

$\mathrm{Yu}$ Z. 2011. Holocene carbon flux histories of the world's peatlands: Global carbon-cycle implications. The Holocene 21: 761-774.

Zak D. \& Gelbrecht J. 2007. The mobilisation of phosphorus, organic carbon and ammonium in the initial stage of fen rewetting (a case study from NE Germany). Biogeochemistry 85: 141-151.

Zak D., Gelbrecht J., Wagner C. \& Steinberg C.E.W. 2008. Evaluation of phosphorus mobilization potential in rewetted fens by an improved sequential chemical extraction procedure. European Journal of Soil Science 59: 1191-1201. 
Zak D., Wagner C., Payer B., Augustin J. \& Gelbrecht J. 2010. Phosphorus mobilization in rewetted fens: the effect of altered peat properties and implications for their restoration. Ecological Applications 20: 1336-1349. 
Table 1. The fixed effects of the linear mixed model analysis for water table level.

\begin{tabular}{l|cccc}
\hline Source & Num. df & Denom. df & F & $p$ \\
\hline Intercept & 1 & 32.00 & 397.483 & $<0.001$ \\
MS & 3 & 32.00 & 35.679 & $<0.001$ \\
Distance & 3 & 96.03 & 61.253 & $<0.001$ \\
MS*Distance & 9 & 96.03 & 37.184 & $<0.001$ \\
\hline
\end{tabular}

MS = Management status

Table 2. Pairwise LSD comparisons between management statuses for water table levels.

\begin{tabular}{ll|ccc}
\hline $\begin{array}{l}\text { Management } \\
\text { status 1 }\end{array}$ & $\begin{array}{l}\text { Management } \\
\text { status 2 }\end{array}$ & $\begin{array}{c}\text { Mean difference } \\
(1-2)\end{array}$ & SE \\
\hline Pristine & Drained & 30.782 & 3.761 & $<0.001$ \\
& Res 5 & -3.322 & 3.761 & 0.384 \\
& Res 10 & 0.993 & 3.761 & 0.794 \\
Drained & Res 5 & -34.104 & 3.761 & $<0.001$ \\
& Res 10 & -29.789 & 3.761 & $<0.001$ \\
Res 5 & Res 10 & 4.315 & 3.761 & 0.260 \\
\hline
\end{tabular}

for all comparisons $\mathrm{df}=32$, Res $5=$ Restored 5 years ago, Res $10=$ Restored 10 years ago

Table 3. The summary of principal component analysis of water chemistry. Three first principal components (PC) and their correlations with studied water chemical variables (eigenvectors) are shown.

\begin{tabular}{lccc}
\hline & PC1 & PC2 & PC3 \\
\hline Eigenvalue & 2.625 & 2.157 & 1.271 \\
\% of variance explained & 32.8 & 27.0 & 15.9 \\
cumulative \% of variance explained & 32.8 & 59.8 & 75.7 \\
Monte Carlo p & $<0.001$ & $<0.001$ & 0.081 \\
\hline Eigenvectors & & & \\
pH & -0.932 & 0.070 & -0.103 \\
EC & -0.733 & 0.451 & -0.049 \\
$\mathrm{Ca}$ & -0.580 & 0.511 & 0.215 \\
$\mathrm{Na}$ & -0.420 & 0.134 & 0.805 \\
$\mathrm{Fe}$ & -0.392 & 0.407 & -0.676 \\
$\mathrm{P}$ & 0.400 & 0.670 & 0.230 \\
$\mathrm{~N}$ & 0.404 & 0.745 & -0.200 \\
$\mathrm{DOC}$ & 0.479 & 0.706 & 0.114 \\
\hline
\end{tabular}


Table 4. Euclidean distances (ED) and results of MRPP analysis between subgroups in the principal component analysis of water chemistry. First three axes (principal components) were included in the calculation.

\begin{tabular}{|c|c|c|c|c|c|c|}
\hline \multicolumn{3}{|c|}{ Subgroups } & ED & $\mathrm{T}$ & A & $p$ \\
\hline 1 & vs. & 2 & 5.172 & -3.831 & 0.239 & 0.003 \\
\hline 1 & vs. & 3 & 5.290 & -5.234 & 0.274 & 0.001 \\
\hline 1 & vs. & 4 & 4.597 & -2.801 & 0.168 & 0.017 \\
\hline 1 & vs. & 5 & 4.308 & -3.035 & 0.143 & 0.012 \\
\hline 1 & vs. & 6 & 4.041 & -2.805 & 0.144 & 0.018 \\
\hline 1 & vs. & 7 & 4.143 & -3.156 & 0.152 & 0.009 \\
\hline 2 & vs. & 3 & 3.044 & -1.061 & 0.035 & 0.142 \\
\hline 2 & vs. & 4 & 3.174 & 0.977 & -0.034 & 0.864 \\
\hline 2 & vs. & 5 & 3.396 & -1.189 & 0.034 & 0.120 \\
\hline 2 & vs. & 6 & 3.124 & -1.523 & 0.042 & 0.080 \\
\hline 2 & vs. & 7 & 3.658 & -5.001 & 0.170 & 0.001 \\
\hline 3 & vs. & 4 & 2.988 & -1.252 & 0.038 & 0.112 \\
\hline 3 & vs. & 5 & 2.892 & -1.383 & 0.040 & 0.095 \\
\hline 3 & vs. & 6 & 2.677 & -1.761 & 0.050 & 0.059 \\
\hline 3 & vs. & 7 & 3.763 & -9.011 & 0.327 & $<0.001$ \\
\hline 4 & vs. & 5 & 3.017 & 0.705 & -0.018 & 0.737 \\
\hline 4 & vs. & 6 & 2.729 & 0.668 & -0.016 & 0.722 \\
\hline 4 & vs. & 7 & 3.174 & -3.390 & 0.089 & 0.007 \\
\hline 5 & vs. & 6 & 2.156 & 1.387 & -0.038 & 0.997 \\
\hline 5 & vs. & 7 & 3.047 & -3.915 & 0.111 & 0.004 \\
\hline 6 & vs. & 7 & 2.893 & -5.829 & 0.157 & $<0.001$ \\
\hline
\end{tabular}

Subgroups: 1 = Drained, ditch, $2=$ Drained, peat strip, $3=$ Restored 5 y ago, ditch, $4=$ Restored 5 y ago, peat strip, $5=$ Restored 10 y ago, ditch, $6=$ Restored 10 y ago, peat strip, $7=$ pristine.

$\mathrm{T}=$ test statistic of MRPP, $\mathrm{A}=$ chance-corrected within-group agreement of MRPP

Table 5. ANOVA for principal components (PC1-PC3) and water chemical variables. Average of values for each site are used for calculations over all four management statuses (Pristine, Drained, Res 5, Res 10).

\begin{tabular}{lccc}
\hline & MS & $\mathrm{F}$ & $\mathrm{p}$ \\
\hline PC1 & 3.061 & 1.992 & 0.138 \\
PC2 & 11.538 & 13.303 & $<0.001$ \\
PC3 & 1.061 & 1.421 & 0.257 \\
Ca & 3.781 & 4.976 & 0.006 \\
Fe & 9.916 & 1.796 & 0.166 \\
Na & 0.331 & 2.046 & 0.126 \\
$\mathrm{~N}$ & 1.040 & 10.269 & $<0.001$ \\
P & 0.076 & 6.252 & 0.002 \\
DOC & 926.984 & 3.026 & 0.043 \\
EC & 298.1 & 2.889 & 0.05 \\
Eh7 & 1532.919 & 2.276 & 0.097 \\
pH & 0.307 & 3.737 & 0.02 \\
df (treatment) $=3$, df (error) $=34$ for other variables than N, P, PC1, PC2, PC3 for which df (error) $=28$
\end{tabular}


Table 6. Pairwise LSD comparisons between management statuses for principal components (PC1-PC3) and water chemical variables. Average of values for each site are used for calculations.

\begin{tabular}{|c|c|c|c|c|c|c|c|}
\hline & $\begin{array}{r}\text { (I) Management } \\
\text { status } \\
\text { (J) Management } \\
\text { status } \\
\end{array}$ & Pristine & Pristine & Pristine & Drained & Drained & Res 5 \\
\hline \multirow[t]{3}{*}{ PC1 } & Mean Diff. (I-J) & 1.538 & -0.441 & 0.257 & -1.979 & -1.281 & 0.698 \\
\hline & SE & 0.816 & 0.569 & 0.554 & 0.826 & 0.816 & 0.569 \\
\hline & $\mathrm{p}$ & 0.070 & 0.446 & 0.646 & 0.024 & 0.128 & 0.231 \\
\hline \multirow[t]{3}{*}{ PC2 } & Mean Diff. (I-J) & -1.111 & -2.548 & -1.940 & -1.438 & -0.829 & 0.608 \\
\hline & SE & 0.613 & 0.428 & 0.416 & 0.621 & 0.613 & 0.428 \\
\hline & $\mathrm{p}$ & 0.081 & $<0.001$ & $<0.001$ & 0.028 & 0.187 & 0.166 \\
\hline \multirow[t]{3}{*}{ PC3 } & Mean Diff. (I-J) & 0.749 & 0.307 & 0.739 & -0.442 & -0.010 & 0.431 \\
\hline & SE & 0.569 & 0.397 & 0.386 & 0.576 & 0.569 & 0.397 \\
\hline & $\mathrm{p}$ & 0.199 & 0.446 & 0.066 & 0.450 & 0.986 & 0.287 \\
\hline \multirow[t]{3}{*}{$\mathrm{Ca}$} & Mean Diff. (I-J) & -1.542 & -0.665 & -0.800 & 0.876 & 0.741 & -0.135 \\
\hline & SE & 0.401 & 0.401 & 0.390 & 0.411 & 0.401 & 0.401 \\
\hline & $\mathrm{p}$ & $<0.001$ & 0.106 & 0.048 & 0.040 & 0.073 & 0.738 \\
\hline \multirow[t]{3}{*}{$\mathrm{Fe}$} & Mean Diff. (I-J) & -0.201 & -1.072 & -2.204 & -0.871 & -2.003 & -1.132 \\
\hline & SE & 1.080 & 1.080 & 1.051 & 1.108 & 1.080 & 1.080 \\
\hline & $\mathrm{p}$ & 0.853 & 0.328 & 0.043 & 0.437 & 0.072 & 0.302 \\
\hline \multirow[t]{3}{*}{$\mathrm{Na}$} & Mean Diff. (I-J) & -0.151 & 0.216 & 0.247 & 0.367 & 0.399 & 0.032 \\
\hline & SE & 0.185 & 0.185 & 0.180 & 0.189 & 0.185 & 0.185 \\
\hline & $\mathrm{p}$ & 0.418 & 0.251 & 0.178 & 0.061 & 0.038 & 0.865 \\
\hline \multirow[t]{3}{*}{$\mathrm{N}$} & Mean Diff. (I-J) & -0.262 & -0.793 & -0.487 & -0.531 & -0.225 & 0.306 \\
\hline & SE & 0.209 & 0.146 & 0.142 & 0.212 & 0.209 & 0.146 \\
\hline & $\mathrm{p}$ & 0.221 & $<0.001$ & 0.002 & 0.019 & 0.292 & 0.046 \\
\hline \multirow[t]{3}{*}{$\mathrm{P}$} & Mean Diff. (I-J) & -0.145 & -0.021 & -0.077 & -0.196 & -0.062 & 0.134 \\
\hline & SE & 0.073 & 0.051 & 0.049 & 0.074 & 0.073 & 0.051 \\
\hline & $\mathrm{p}$ & 0.843 & $<0.001$ & 0.132 & 0.013 & 0.401 & 0.014 \\
\hline \multirow[t]{3}{*}{ DOC } & Mean Diff. (I-J) & -17.589 & -22.976 & -13.921 & -5.387 & 3.668 & 9.055 \\
\hline & SE & 8.042 & 8.042 & 7.827 & 8.251 & 8.042 & 8.042 \\
\hline & $\mathrm{p}$ & 0.036 & 0.007 & 0.084 & 0.518 & 0.651 & 0.268 \\
\hline \multirow[t]{3}{*}{$\mathrm{EC}$} & Mean Diff. (I-J) & -12.441 & -10.368 & -9.628 & 2.072 & 2.813 & 0.741 \\
\hline & SE & 4.668 & 4.668 & 4.543 & 4.789 & 4.668 & 4.668 \\
\hline & $\mathrm{p}$ & 0.012 & 0.033 & 0.041 & 0.668 & 0.551 & 0.875 \\
\hline \multirow[t]{3}{*}{$\mathrm{pH}$} & Mean Diff. (I-J) & -0.382 & 0.002 & -0.066 & 0.385 & 0.316 & -0.069 \\
\hline & SE & 0.132 & 0.132 & 0.128 & 0.135 & 0.132 & 0.132 \\
\hline & $\mathrm{p}$ & 0.006 & 0.986 & 0.609 & 0.007 & 0.022 & 0.606 \\
\hline \multirow[t]{3}{*}{$\mathrm{E}_{\mathrm{h} 7}$} & Mean Diff. (I-J) & -22.035 & 6.519 & 3.596 & 28.554 & 25.631 & -2.923 \\
\hline & SE & 11.924 & 11.924 & 11.606 & 12.234 & 11.924 & 11.924 \\
\hline & $\mathrm{p}$ & 0.073 & 0.588 & 0.759 & 0.026 & 0.039 & 0.808 \\
\hline
\end{tabular}

Res $5=$ Restored 5 years ago, Res $10=$ Restored 10 years ago

Values are given as $\mathrm{mg} / \mathrm{l}$ for $\mathrm{Ca}, \mathrm{Fe}, \mathrm{Na}, \mathrm{N}, \mathrm{P}$ and $\mathrm{DOC}$, as $\mu \mathrm{S} / \mathrm{cm}$ for $\mathrm{EC}$ and as $\mathrm{mV}$ for $\mathrm{E}_{\mathrm{h}}$ 
Table 7. Between subject effects of repeated measures ANOVA for principal components (PC1-PC3) and water chemical variables over sampling locations (ditch/peat strip) and management statuses (Drained, Res 5 and Res 10).

\begin{tabular}{lcccccc}
\hline & \multicolumn{3}{c}{ Location (factor 1) } & \multicolumn{3}{c}{ Location*Management status } \\
& MS & $\mathrm{F}$ & $\mathrm{p}$ & $\mathrm{MS}$ & $\mathrm{F}$ & $\mathrm{p}$ \\
\hline PC1 & 8.427 & 5.418 & 0.031 & 12.929 & 8.312 & 0.003 \\
PC2 & 0.431 & 0.472 & 0.500 & 1.235 & 1.353 & 0.282 \\
PC3 & 1.103 & 4.326 & 0.051 & 0.588 & 2.306 & 0.127 \\
$\mathrm{Ca}$ & 0.034 & 0.050 & 0.824 & 1.889 & 2.831 & 0.078 \\
$\mathrm{Fe}$ & 12.485 & 2.804 & 0.107 & 1.625 & 0.365 & 0.698 \\
$\mathrm{Na}$ & 0.011 & 0.119 & 0.733 & 0.076 & 0.807 & 0.457 \\
$\mathrm{~N}$ & 0.064 & 0.297 & 0.592 & 2.463 & 11.485 & 0.001 \\
$\mathrm{P}$ & 0.012 & 0.542 & 0.470 & 0.001 & 0.06 & 0.942 \\
$\mathrm{DOC}$ & 2202.333 & 11.613 & 0.002 & 3950.822 & 20.832 & $<0.001$ \\
$\mathrm{EC}$ & 252.118 & 2.261 & 0.145 & 282.926 & 2.537 & 0.099 \\
$\mathrm{Eh}$ & 765.824 & 1.042 & 0.317 & 194.661 & 0.265 & 0.769 \\
pH & 1.632 & 14.877 & 0.001 & 1.910 & 17.408 & $<0.001$ \\
\hline df (Location) $=1, \mathrm{df}$ (Location*Management status) $=2$, & &
\end{tabular}

$\mathrm{df}$ (error) $=25$ for other variables than N, P, PC1, PC2, PC3 for which $\mathrm{df}$ (error) $=19$

Table 8. Pairwise LSD comparisons between sampling locations (ditch/peat strip) for principal components (PC1-PC3) and water chemical variables for different management statuses.

\begin{tabular}{|c|c|c|c|c|c|c|c|c|c|}
\hline & \multicolumn{3}{|c|}{ Drained } & \multicolumn{3}{|c|}{ Res 5} & \multicolumn{3}{|c|}{ Res 10} \\
\hline & $\begin{array}{l}\text { MD } \\
\text { (Ditch- } \\
\text { Strip) }\end{array}$ & $\mathrm{SE}$ & $p$ & $\begin{array}{l}\text { MD } \\
\text { (Ditch- } \\
\text { Strip) }\end{array}$ & SE & $\mathrm{p}$ & $\begin{array}{l}\text { MD } \\
\text { (Ditch- } \\
\text { Strip) }\end{array}$ & SE & $p$ \\
\hline PC1 & -3.938 & 1.018 & 0.001 & 0.790 & 0.588 & 0.195 & 0.118 & 0.558 & 0.835 \\
\hline PC2 & -0.190 & 0.780 & 0.811 & 0.897 & 0.450 & 0.061 & -0.022 & 0.427 & 0.960 \\
\hline PC3 & -0.103 & 0.412 & 0.806 & -0.820 & 0.238 & 0.003 & -0.173 & 0.226 & 0.453 \\
\hline $\mathrm{Ca}$ & 0.660 & 0.385 & 0.099 & -0.606 & 0.385 & 0.128 & -0.201 & 0.365 & 0.587 \\
\hline $\mathrm{Fe}$ & 0.374 & 0.995 & 0.710 & 0.920 & 0.995 & 0.364 & 1.543 & 0.944 & 0.115 \\
\hline $\mathrm{Na}$ & 0.088 & 0.145 & 0.548 & -0.169 & 0.145 & 0.255 & -0.005 & 0.138 & 0.974 \\
\hline $\mathrm{N}$ & -0.743 & 0.378 & 0.064 & 1.067 & 0.218 & $<0.001$ & -0.060 & 0.207 & 0.775 \\
\hline $\mathrm{P}$ & -0.056 & 0.122 & 0.652 & -0.043 & 0.071 & 0.549 & -0.016 & 0.067 & 0.814 \\
\hline DOC & -46.390 & 6.492 & $<0.001$ & 3.004 & 6.492 & 0.648 & 5.709 & 6.159 & 0.363 \\
\hline EC & 13.312 & 4.978 & 0.013 & -0.056 & 4.978 & 0.991 & -0.510 & 4.723 & 0.915 \\
\hline $\mathrm{pH}$ & 1.086 & 0.156 & $<0.001$ & $-8.88 \mathrm{E}^{-16}$ & 0.156 & 1.000 & -0.060 & 0.148 & 0.689 \\
\hline $\mathrm{E}_{\mathrm{h} 7}$ & -3.363 & 12.777 & 0.795 & -4.122 & 12.777 & 0.750 & -14.730 & 12.121 & 0.236 \\
\hline
\end{tabular}




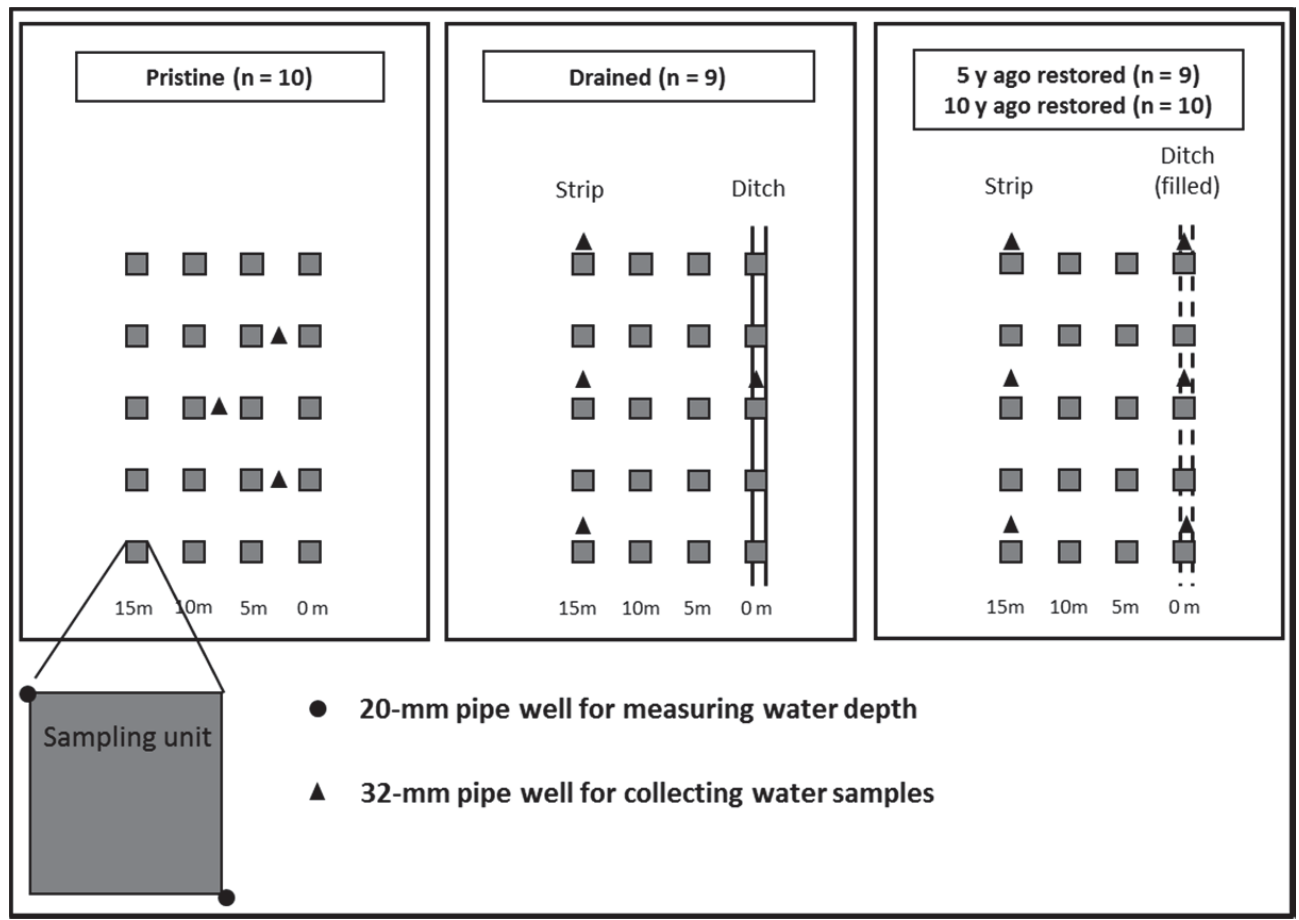

Fig. 1. Study set ups for measuring water table depth and collecting water samples at pristine, drained and restored sites. Distances (m) refer to distance of sampling units to ditches at restored and drained sites. A similar grid of sampling units was laid at pristine sites. 


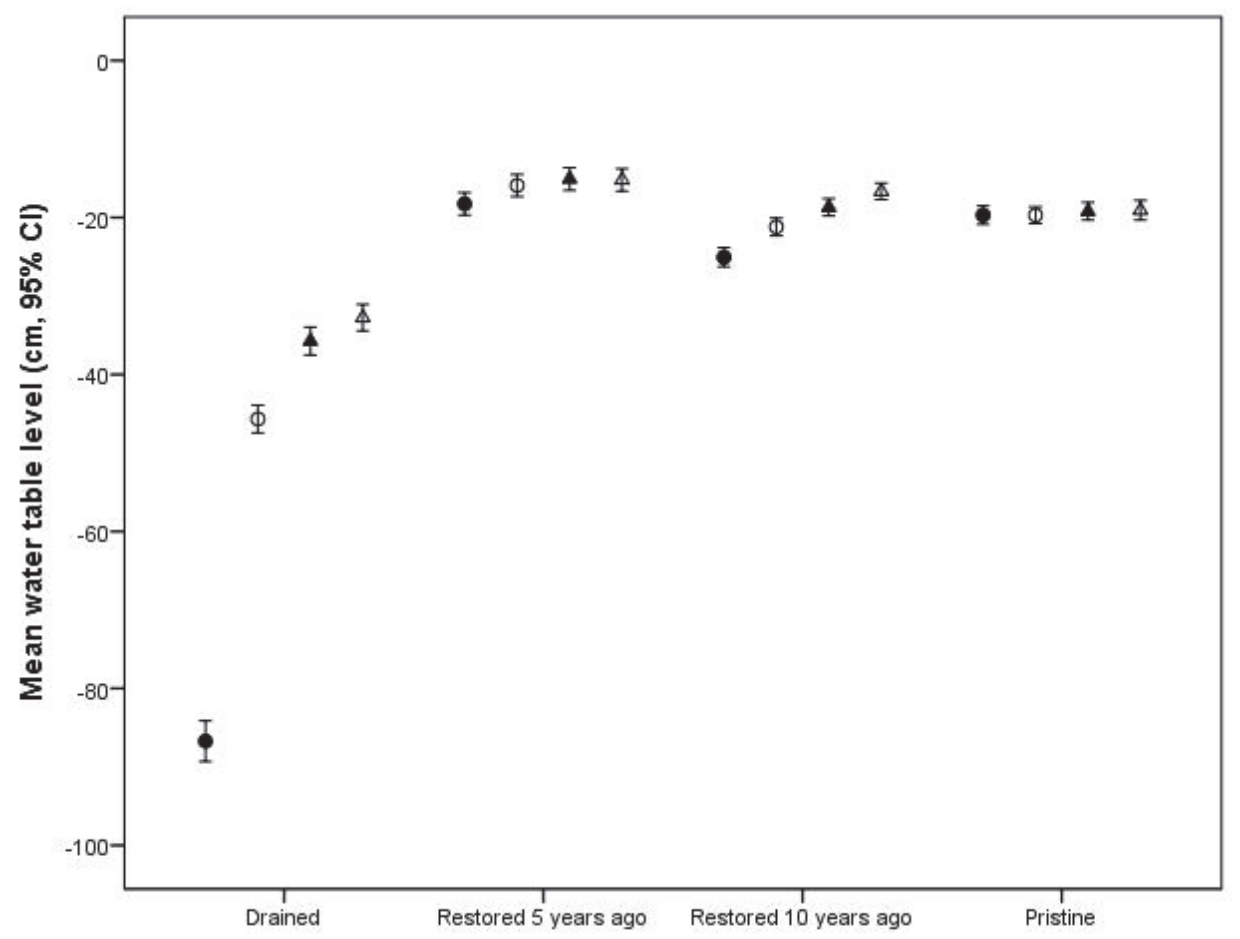

Fig. 2. Mean water table levels with $95 \% \mathrm{CI}$ at different distances to the ditch during summer. Symbols: filled circle $=0 \mathrm{~m}$ from the ditch, open circle $=5 \mathrm{~m}$ from the ditch, filled triangle $=10 \mathrm{~m}$ from the ditch, and open triangle $=15 \mathrm{~m}$ from the ditch. The figures consist of five measurements (May-September) from five wells at each distance to ditch. 


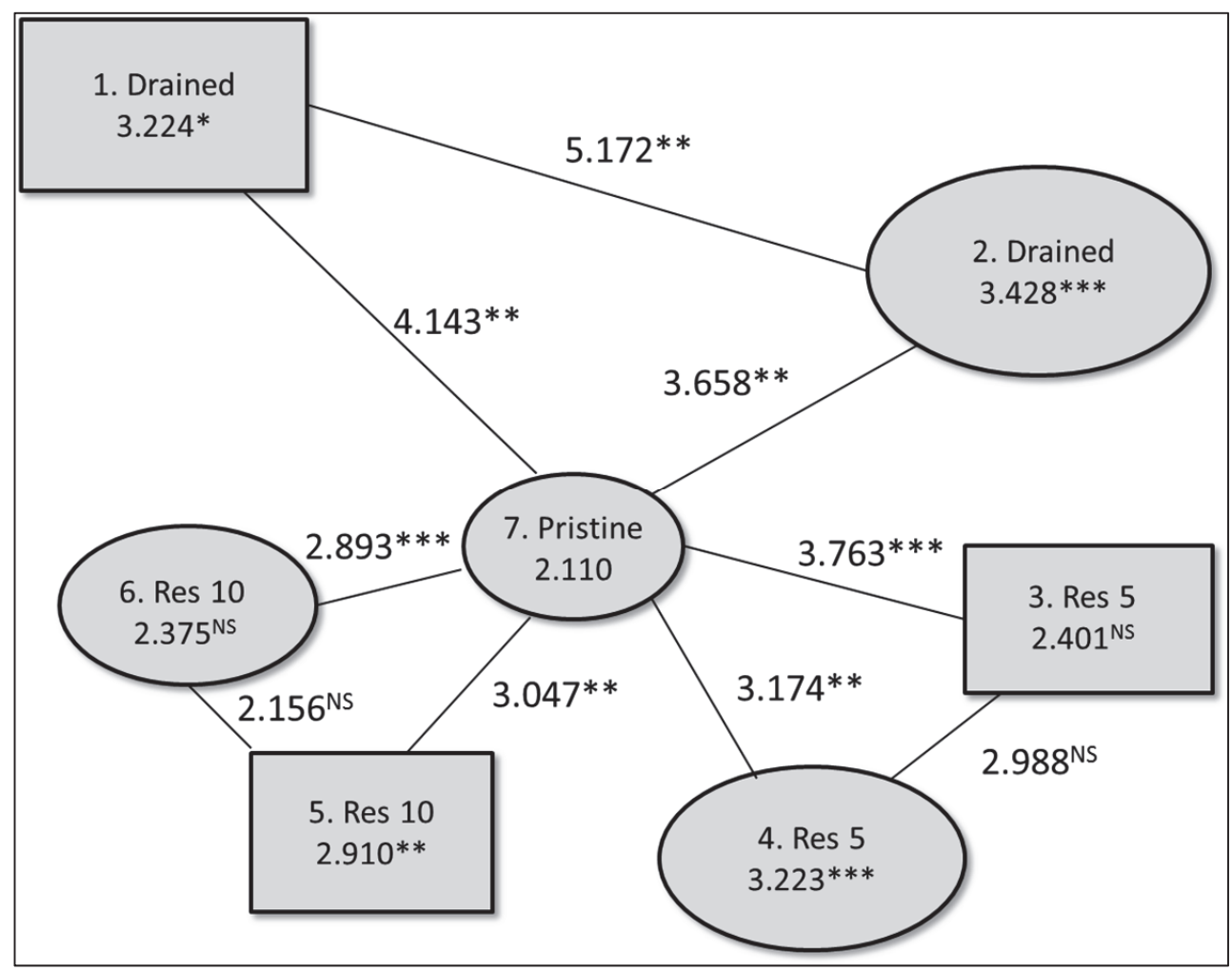

Fig. 3. Average Euclidean distances (ED) and their statistical significances between subgroups 1-7 for the three dimensional resolution of principal component analysis (PCA) of water chemistry. The values next to a line joining two subgroups show the average ED between the groups, and the symbols thereafter refer to the statistical difference from MRPP test between the subgroups. To allow more comprehensive utilization of the results than discussed in the text, average EDs within subgroups are shown inside boxes (samples from ditches) and ellipses (samples from peat strips). The symbols following the average within subgroup ED refer to the statistical significance from independent samples t-tests comparing the average EDs within a given subgroup to the average ED within pristine subgroup. Statistical significance of results: ${ }^{* * *}: \mathrm{p}<0.001,{ }^{* *}: \mathrm{p}<0.01,{ }^{*} \mathrm{p}<0.05$, ns: nonsignificant. A complete list of distances between subgroups is given in Table 4 . 

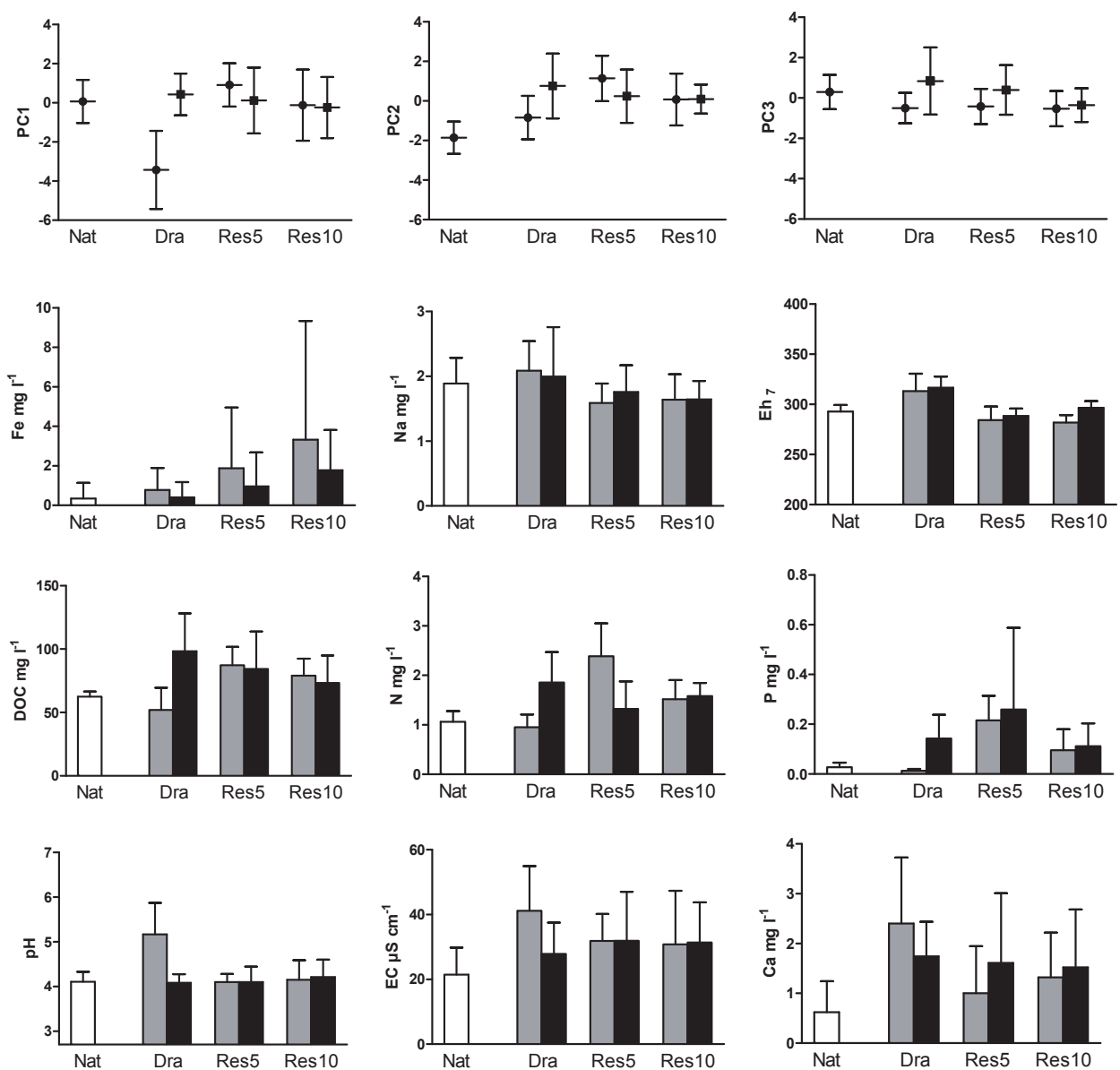

Fig. 4. Average values (+- $1 \mathrm{SD}$ ) of PC1-PC3 and water chemical variables for different management statuses from samples collected from ditches (gray bars) and peat strips (black bars). Note that for PC1, PC2, PC3, N and P, figures show the average values over all sites in each group ( $\mathrm{n}=10,9,9$ and 10 for Pri, Dra, Res 5 and Res 10, respectively). However, only the sites with $\mathrm{N}$ and $\mathrm{P}$ analyzed both from ditch and peat strip at each site were included in the ANOVA and subsequent pairwise tests. 